\title{
10. National counter-terrorism responses: United States of America
}

\author{
Michael Robillard
}

\section{BACKGROUND}

The historical context of United States (US) counter-terrorism legislation, strategy and policy can largely be traced back to a Cold War understanding of future threats. From 1970 to roughly around the time of the Iran hostage crisis (1979-1981), the bulk of terrorist threats were anticipated by the US as originating from radical leftist and radical communist state-sponsored groups, such as the Baader-Meinhof Group ('Red Army Faction') operating out of West Germany. The Iran hostage crisis marked a significant shift in terms of US acknowledgment of a new kind of terrorist threat emerging within the geopolitical arena, one that was relatively autonomous and motivated by religious extremism, as opposed to one that was state-sponsored and motivated by communist ideology. The bombings of the US Embassy in Beirut, Lebanon in 1983 by religious extremists going by the name of the Islamic Jihad, further re-affirmed this newly emerging threat picture.

The 1980s and the Reagan administration marked a further waning of this Cold War terrorist threat picture, coupled with a significant re-structuring of the US military and the Department of Defense (DOD). The GoldwaterNichols Act (1986) brought about significant reforms and re-structuring to the US military division of labour. Among some of the major reforms relevant to counter-terrorism were the creation of the concept of the Joint Task Force (JTF), the official formation of the Joint Special Operations Command (JSOC), and the official formation of a DOD agency, US Central Command (CENTCOM), specifically to oversee the Central and Middle Eastern theatre of operations. A further fallout from the Goldwater-Nichols reforms was a more stringent clarification of Title 10 versus Title 50 legislation: outlining the jurisdictional strictures and institutional division of labour between agencies and members operating under the auspices of the DOD (Title 10), versus those operating under the auspices of the Central Intelligence Agency (Title 50). In terms of legislative authority, Title 10 typically covers the legal 
authorisation and permission for the military to use deadly force, while Title 50 concerns legal authorisation for the Central Intelligence Agency (CIA) to conduct intelligence-gathering and covert operations. These series of reforms would usher in a new DOD infrastructure that allowed for overall greater inter-agency and inter-service integration, greater forward posturing and in-theatre power project, and overall institutional nimbleness for future conflicts. The formation and codification of the agencies and sub-agencies coming out of the Goldwater-Nichols Act is highly pertinent, since they provide the basic inter-agency blueprint upon which the US presently conducts its wars, to include the current 'war on terror'.

With the winding down of the Cold War, the US terrorist threat picture throughout much of the Bush and Clinton administrations went from one of state-sponsored terrorist groups originating from a single, monolithic adversary to a series of fractured and unrelated one-off attacks stemming from a variety of foreign and domestic sources: the World Trade Center bombing 1993, the Oklahoma City bombing 1995, the US Embassy bombings in Tanzania and Kenya 1998, and the bombing of the USS Cole in 2000. During this post-Cold War period, and perhaps largely because of it, US counter-terrorism strategy and thinking could best be described as reactive in nature, as US military and special operations groups functioned primarily in an 'advise and assist' capacity only. The attacks initiated by al-Qaeda on 11 September 2001, however, radically shifted US counter-terrorism strategy from a fundamentally reactive to fundamentally preventive posture, both at home and abroad. This shift from reaction to prevention resulted in significant re-structuring and re-defining of purposes for many US domestic and DOD agencies, as well as a critical re-thinking of the post-9/11 threat picture and overall operational environment. This shift to a primarily preventive warfighting and counter-terrorist strategy posture can best be seen in the subsequent US invasions of Afghanistan in 2001 and Iraq in 2003, by the expansive military policies instituted by Secretary of Defense Donald Rumsfeld from 2003 to 2005, and by the unilateral tone of the so-called 'Bush Doctrine'. Domestically speaking, this shift towards active prevention can likewise be seen in the enhanced surveillance procedures and heightened border security protocols adopted as part of the Patriot Act of 2001.

The US counter-terrorism strategy during the Bush administration focused mainly on the commitment of a robust troop presence in Iraq and Afghanistan, as demonstrated by the 2007 'Surge', which placed 20000 additional troops in the Iraq region. In conjunction with increased troop presence, the Bush administration focused primarily on the securing of key positional and infrastructural assets (Bagram, Baghdad, Fallujah, and so on) coupled with the erecting of new governmental institutions led by regionally elected leadership (Karzai in Afghanistan, al-Maliki in Iraq). During the Bush administration, the controversial Guantanamo Bay detention camp was also established, which 
allowed for the indefinite detention of detainees without trial for suspected ties to terrorist organisations, garnering much criticism from the international community. While there is little evidence of a strong al-Qaeda presence in Iraq at the outset of the Iraq War in 2003, towards the end of the Bush administration the presence of al-Qaeda in Iraq began to pick up increased momentum. This would form the proto-entity that would eventually crystallise into the Islamic State (IS; also referred to interchangeably by many media outlets as ISIS/ISIL) in and around 2013.

As the Bush administration wound down and handed off authority to the Obama administration, US counter-terrorism strategy shifted along with the terrorism threat picture. While the Bush administration's counter-terrorism strategy will likely be most remembered for its emphasis on 'boots on the ground' and detention, the Obama administration will likely be remembered for its significant drawdown of troop presence in both Afghanistan and Iraq, a drawdown of detainees at Guantanamo, and its heightened emphasis on the use of targeted drone strikes and special operations raids (for example, the killings of Awlaki in Yemen 2011, and bin Laden in Pakistan 2011).

The Obama administration's use of targeted killing marked a new precedent in the 'war on terror'. Compared to the Bush administration, which carried out 48 drone strikes in Pakistan, killing 377 to 588 people according to the New America Foundation, the Obama administration carried out 35 strikes in the same region, killing between 1907 and 3067 people. Some have seen this shift towards a drone strike policy to be a net positive.

There has nonetheless been much criticism of the Obama administration's use of drone strikes, primarily on the grounds that such strikes are serving to kill many innocent civilians instead of legitimate terrorist threats (Brooks, 2015). Furthermore, critics have also argued that the use of drone strikes has not succeeded in thwarting terrorist leadership but instead has functioned to create resentment in the local populace and actually promote support for terrorist groups (Cole, 2016; Sharp, 2016). During this time period, the US also saw several 'inspired' lone wolf terrorist attacks on American soil, such as the Fort Hood shooting (2009), the Boston Marathon bombing (2013) and the San Bernardino shooting (2015).

The US saw the Islamic State (IS) rise to prominence in 2014 in terms of funding, recruitment, internet presence, weapons capabilities, and territorial gains in Syria, Iraq and Lebanon. At its peak strength, in 2015, IS appeared more like a conventional fighting force than a non-conventional insurgent group. In 2017, US Special Forces units, working in conjunction with Iraqi and Kurdish forces, helped to reclaim the majority of Mosul from IS forces. The Trump administration's use of decapitation strikes and special operations raids, particularly the Syrian raid in October 2019, led to the successful killing of IS leader Abu Bakr al-Baghdadi, and helped to significantly wither IS's 
strategic footprint in the area. Since then, much controversy has centred around the US withdrawal from Northern Syria (Schmitt et al., 2019).

\section{THREATS}

\section{Terrorist Group Classification}

While there has been much dispute within the legal community regarding the specific definitions, terrorism is commonly understood as involving an actor or actors who use violence or the threat of violence, against non-combatants, in order to further some ideological end. There is, of course, a danger in conceptually mixing different terrorist groups under this broad umbrella, (for example, mixing IS with the Irish Republican Army, IRA); hence, further parsing of different kinds of terrorist groups is necessary. We can broadly think of terrorist actors fitting into the following conceptual categories:

1. Single actors or anarchists: actors who use violence for a cause but have no followers (for example, Tim McVeigh, the Unabomber).

2. 'Westphalian' terrorists: insurgents or secessionist movements that use terrorist means (Tamil Tigers, IRA, Basque). These groups use violence against civilian populations in order to politically and symbolically demonstrate to the populace the incapacity of the existing state to protect them. These groups are often thought to be, in principle, appeasable.

3. State-sponsored terrorism: insurgent groups that use terroristic attacks on innocents in coordination with state funding and guidance (for example, Hezbollah, Serbian Black Hand). Here, there is a spectrum of 'sponsorship', going from direct guidance and funding, to guidance without funding or funding without guidance, to 'benign abetment'. For instance, Iran's involvement with Hezbollah placed it on the state-sponsorship list.

4. Tribe-versus-tribe terrorism: involves the use of terrorist tactics, mainly by Pakistani and Afghani tribes for the purpose of revenge or reprisal. This type of terrorism is most prevalent in the Federally Administered Tribal Area (FATA) region of Pakistan. It is important to note this kind of terrorism, since it resembles other kinds of terrorism, but the intention of the violent act is quite different.

5. Jihadi terrorism: these groups and individuals target not just the West but also Western interests, sources of Western influence, and also those countries and their governance systems that are perceived as being supportive of, and/or sympathetic to, Western ideals. These groups or individuals also generally have some variation of a vision that sees the restoration of an Islamic Caliphate as a goal. While there is a risk of over-inflating the importance of this category of terrorism within the overall US national 
defence strategy, it remains a sufficiently salient threat to warrant a working category of its own.

\section{Jihadi Terrorist Threats}

The US and the global counter-terrorism (CT) community have developed an increasingly better-informed and more nuanced understanding of terrorist organisations such as al-Qaeda, IS, Boko Haram and the Nusra Front that can be viewed as ideological offshoots of jihadism (used here to mean groups that espouse an ideological commitment to using violence, and in particular violent terrorist action, in defence of what they view as an attack upon Islam itself). The jihadist movement is a fundamentally diffuse and heterogeneous amalgamation of different terrorist groups that include: core al-Qaeda and associates (that is, those which have formally sworn bayat, or official allegiance, to al-Qaeda), those committed to the jihadist ideology but which have not sworn official allegiance (that is, IS), and other inspired individuals and networks. Al-Qaeda and other jihadist groups have decentralised, for two likely main reasons: widespread variation in objectives, personalities, geography and ethnic groups; and because of effective counter-terrorism tactics and pressures. A third partial explanation for this diffuse organisational structure, however, is that it is being done deliberately (Jones, 2014, pp. 25-62).

The structure of the jihadist movement shares several structural similarities to the Soviet model of ideological propagation in that it is organised by a centralised ideology and geographic region, a series of insurgent groups, and a 'jihadi internationale', so to speak. However, while the communist internationale sought to spread communism largely via soft power means and propaganda, coupled with back-and-forth communication from the USSR, the Jihadist model seeks to spread jihad internationally, and mostly with no such back-and-forth communication to a centralised authority. Awlaki's creation of Inspire magazine, circa 2010, sought to create 'open source jihad' by encouraging jihadi adherents to spread the message on their own, without necessarily becoming affiliates who communicated back to some higher organisational authority.

The jihadist movement has served as a nexus point and organisational hub for several different radicalised demographics, either as a touchstone of authentic ideological commitment, or as a wave of sentiment being taken advantage of by various opportunist groups. These groups arguably carve into the following six categories:

1. Regional Sunni versus Shia conflicts (Iraq, Syria).

2. Regional Muslim (old Islamic Caliphate) versus old Christian West (Mali, Niger, and so on). 
3. Other disgruntled Sunnis (Saudi Arabia, Egypt, Kuwait).

4. Disenfranchised Westerners (particularly second-generation Muslims).

5. Petty criminals, violence seekers and adventurists.

6. War profiteers.

Much debate still exists between counter-terrorism experts as to the extent to which different Jihadist groups differ over such issues as the scope of the Caliphate, as well as the 'near' versus 'far' enemy (that is, the extent to which Westerners are the 'real' enemy as opposed to local Shia Muslims). In 1992 there were just three groups. One year after 9/11, there were 22, but by 2013 this had increased further to 49 .

\section{Al-Qaeda}

Al-Qaeda is a radical Salafist terrorist group whose stated mission is to establish a true Islamic Caliphate in the Middle East and achieve global Islamic domination, and to rid the Middle East of what it perceives as the corrupting influences of the West. Formed in 1988 by Osama bin Laden during the Soviet-Afghan War, al-Qaeda derives much of its militant Islamic purism from the writings of bin Laden's predecessor and mentor, Sayyid Qutb. Al-Qaeda's ideology parses its military and terrorism objectives into attacks against the 'near enemy' of secularised Islamic governments within the region of the Middle East, such as Saudi Arabia, and the 'far enemy' of foreign Western influence, most particularly that of the United States (Byman, 2015). While al-Qaeda and its affiliates are primarily based in the Middle East, particularly in Saudi Arabia, Syria, Iraq and Afghanistan, its network spans the entire globe. This allows for continued attacks against the far enemy of the West and the Western-influenced nations to be conducted, prior to a decisive defeat of near enemies within the Arab speaking world. Accordingly, key attacks against the West conducted by al-Qaeda include the bombings of US embassies in Kenya and Tanzania in 1998, the attack on the USS Cole in 2000, and the attacks on the World Trade Center and the Pentagon on 11 September 2001. Following the death of Osama bin Laden in a 2011 US Special Forces raid in Pakistan, leadership of al-Qaeda fell into the hands of the Egyptian Ayman Zawahiri. Within the global terrorism threat picture, al-Qaeda has been much less active during recent years as its prominence and recruitment efforts have been somewhat overshadowed by the rise of ISIS.

\section{The Islamic State of Iraq and Syria}

In his 'Worldwide Threat Assessment of the US Intelligence Community to the Senate Armed Services Committee', Director of National Intelligence James 
R. Clapper referred to ISIS as 'the preeminent terrorist threat because of its self-described Caliphate in Syria and Iraq, its branches and emerging branches in other countries, and its increasing ability to direct and inspire attacks against a wide range of targets around the world' (Clapper, 2016).

Clapper notes that an estimated 36500 foreign fighters (to include 6600 Westerners) have travelled to Syria from more than 100 countries to join the organisation since 2012. Clapper also notes ISIS's continued exploitation of weak governance in Syria and surrounding areas as a safe haven and space of expansion for its cause. He likewise notes the benefit ISIS will likely continue to gain from new young recruits adept at exploiting social media, encryption, the dark web and virtual technologies.

While al-Qaeda's primary focus has been on ridding the Middle East of Western influence, with the establishment of the Islamic Caliphate being an ambition in the distant future, ISIS's main mission and priority is to establish the Caliphate in the here and now. Accordingly, as per Islamic law and prophecy, the priority of ISIS's mission is the capturing and defending of the actual land mass of the Caliphate. In contrast, because of its less ambitious timeline, al-Qaeda's mission is not similarly dependent upon such positional and territorial priorities.

Despite early successes in 2014 and 2015, the strength and influence of ISIS has considerably waned in recent years after suffering major positional and territorial losses in both Raqqa and Aleppo, Syria. The death by suicide of its key leader, Abu Bakr al-Baghdadi, during a US Special Forces raid in October 2019 , further functioned as another decisive blow to the organisation's leadership, morale and international reputation. At present, al-Qaeda and ISIS are competing for leadership and control over future recruits, as well as the dominant vision and direction of future Islamic jihadist efforts both regionally and globally.

\section{Tactics and Terror Acts}

Al-Qaeda and ISIS have differed in their use of terror tactics in accordance with their diverging strategic goals and visions. Al-Qaeda, for instance, in its ongoing fight against the United States, has relied upon punctuated and spectacular violent acts in order to marshall support and future recruitment from the greater Muslim world, and to pressure the United States, and the West more broadly, to withdraw its presence and influence in the Middle East (Byman, 2015).

Alternatively, the terror tactics of IS are more regionally contained to the Middle East, and are more intimately linked to its effective use of video-based social media to publicise and promote its terror acts. These terror acts include the beheading of high-profile Western journalists, the burning alive of 
a Jordanian military pilot in a cage, the hurling of an alleged homosexual man to his death from a multi-storey building, and the mass execution of innumerable Shia innocents.

The group's social media campaign serves both as terror propaganda, as well as an effective recruitment tool for adherents and sympathisers, since their filmed atrocities are consistent with Sharia law punishments. ISIS also employs the terror tactic of 'open source' jihad, via its online magazine Inspire, which provides do-it-yourself instructions for bomb-making and other terror tactics for would-be Western sympathisers and adherents.

\section{INSTITUTIONAL ARCHITECTURE}

\section{Intelligence Community-Domestic Policing Gap}

Since its creation, the US has had a long history of a deliberate gap between its military and foreign intelligence apparatus and its domestic law enforcement apparatus. This intentional gap, while arguably affording civilians greater immunity from surveillance and privacy obstruction, has nonetheless hampered efficient coordination between the US intelligence community and local law enforcement agencies. Accordingly, prior to 9/11, the integration and coordination between the intelligence community and domestic police was rather poor. Coordination between these two communities is further hindered by the absence of a large, centralised federal law enforcement body. Lastly, the US domestic policing structure itself is layered (for example, at local, county and state levels), with local police actors on the ground often lacking the proper security clearance to gain requisite knowledge of ongoing cases. Without this, they are unable to properly appraise anomalous or suspicious behaviour at the local level (for example, Saudi nationals taking pilot training, but showing no interest in learning how to land an aircraft). Lastly, even if such anomalous or suspicious behaviour is recognised at the local level, at present there is still an absence of an overarching and efficient chain of command, and a lack of horizontal cross-talk, for local authorities to report to in a fast and expedient manner.

\section{Central Intelligence Agency (CIA)}

The Central Intelligence Agency is one of the United States' leading foreign intelligence services, primarily focused on human intelligence (HUMINT). The mission of the CIA is 'to preempt threats and further US national security objectives by collecting intelligence that matters, producing objective all-source analysis, conducting effective covert action as directed by the President, and safeguarding the secrets that help keep our nation safe' (US 
Senate, 2018). The CIA reports to the Director of National Intelligence, functions in an advisory capacity to the President, and has a seat at the National Security Council. The unofficial CIA annual budget is estimated to be around $\$ 52.4$ billion. The number of persons working for the CIA cannot be publicly disclosed, although estimates are somewhere around 21000 employees. With respect to counter-terrorism efforts, the CIA works in conjunction with the National Security Agency (NSA), National Counter-Terrorism Center (NCTC), and the greater US and foreign intelligence community, to gather pertinent intelligence mainly though interpersonal interactions. In the global 'war on terror', the CIA also conducts cyber-operations and covert paramilitary operations under Title 50 authorisation.

\section{National Security Agency (NSA)}

The National Security Agency is the leading United States agency dealing with information and signals intelligence (SIGINT). The NSA technically falls under the auspices of the Department of Defense and works in conjunction with the broader US and foreign intelligence communities. The NSA mission is as follows: 'The National Security Agency/Central Security Service (NSA/CSS) leads the U.S. Government in cryptology that encompasses both Signals Intelligence (SIGINT) and Information Assurance (IA) products and services, and enables Computer Network Operations (CNO) in order to gain a decision advantage for the Nation and our allies' (NSA, 2020). The NSA's yearly budget is estimated at around $\$ 10$ billion (Sahadi, 2013). With respect to counter-terrorism, the NSA functions mainly to gather and interpret bulk electronic surveillance data from internet and phone networks (such as with the PRISM surveillance program leaked by Edward Snowden in 2013).

\section{Department of Homeland Security (DHS)}

The US Department of Homeland Security was created as a direct response to the September 11 attacks. Its mission, to quote Governor Tom Ridge, first DHS director, is 'to develop and coordinate the implementation of a comprehensive national strategy to secure the United States from terrorist threats or attacks. The Office will coordinate the executive branch's efforts to detect, prepare for, prevent, protect against, respond to, and recover from terrorist attacks within the United States' (Ridge, 2002).

The DHS presently has approximately 240000 employees, and is the third-largest Cabinet department after the DOD and Veterans Affairs (DHS, 2020). The DHS also functions as an umbrella organisation for the following sub-agencies: US Citizenship and Immigration Services, US Customs and Border Protection, US Immigration and Customs Enforcement, Transportation 
Security Administration, US Coast Guard, US Secret Service, National Cybersecurity Center and the Federal Emergency Management Agency. In addition to its main role in coordinating between these various sub-agencies and the White House, the DHS is also responsible for the National Terrorism Advisory System. The DHS, in collaboration with the DOJ, has established 'fusion centres' aimed at facilitating information-sharing at the federal level between the CIA, Federal Bureau of Investigation (FBI), DOJ, DOD, and state and local law enforcement agencies. As of 2009, there were 72 DHS fusion centres (DHS, 2020).

\section{National Counter-Terrorism Center (NCTC)}

As a result of the above-mentioned intelligence-policing gap, the National Counter Terrorism Center (under the Department of National Intelligence and DHS) was created as part of the 2004 Intelligence and Terrorism Act (a product of the 9/11 Commission Report). The NCTC functions as the primary node of coordination between the larger intelligence community and domestic law enforcement, as well as serving in an advisory capacity as part of the Counter-Terrorism Support Group (CSG). The NCTC is also responsible for compiling and managing the Terrorist Identities Datamart Environment (TIDE), a database containing over 1200000 identities of individuals suspected of terror links. This database then informs the creation of terrorist watch lists and 'no-fly' lists.

\section{Federal Bureau of Investigation (FBI)}

The FBI functions as the primary, federal law enforcement agency in the United States. Its mission is to protect the American people and uphold the Constitution of the United States. Along with its headquarters in Washington, DC, it has 56 field offices and 350 satellites throughout the US as well as 60 international offices worldwide. The FBI employs approximately 35000 employees and special agents, and in the fiscal year of 2016 had an approximate annual budget of $\$ 8.7$ billion. The FBI technically falls under the supervision of both the Department of Justice (DOJ) and Department of National Intelligence (DNI). The FBI functions as one of the leading counter-terrorism and counter-intelligence organisations in the US, with its primary counter-terrorism efforts focused through its leadership of the Joint Terrorism Task Force (JTTF). 


\section{Joint Terrorism Task Force (JTTF)}

Terrorism-related information moves from the local level to the federal level primarily through the FBI-led Joint Terrorism Task Forces (JTTFs). There are JTTFs based in 103 US cities, and at least one in each of the FBI's 56 field offices. This fact is important, since it shows that the NCTC and DHS do not directly receive local intelligence (mainly because of statutory limitations and concerns of domestic 'spying'). The JTTF model has been criticised over the years for several reasons. For instance, since local police departments are usually only privy to the terrorist threat information that JTTFs provide them, either they are rendered as mere adjuncts to the federal intelligence effort, or the information provided to them is often fundamentally unactionable. FBI-led JTTFs have likewise been criticised both for excessive information-gathering encroaching on civilian privacy, as well for their failure to act responsively to intelligence gathered, as in the case of the 2009 Fort Hood shooting (Jenkins et al., 2014, pp. 8-16).

\section{Counter-Terrorism Support Group (CSG)}

Following the international debacle of the Iran hostage crisis and the failure of Operation Eagle Claw to rescue the hostages, then-President Reagan tasked Vice President George Bush to create the CSG. The CSG is chaired by an NSC representative and includes representatives from the following agencies:

1. Office of the Secretary of Defense.

2. Chief Justice of the Supreme Court.

3. Department of Justice.

4. Federal Bureau of Investigation.

5. State Department (CT specialist).

6. State Department (diplomatic security).

7. Department of Energy (for nuclear considerations).

8. Central Intelligence Agency.

9. Department of National Intelligence.

10. National Counter-Terrorism Center.

Since 9/11, the CSG has met each week, with its main purpose being the generation of courses of action (COAs) for immediately occurring terrorist threats, policy prescriptions, and to generate input for national counter-terrorism strategy. Preliminary COAs generated by the CSG are then forwarded on to a Deputies Committee comprised of the under-secretaries of the aforementioned agencies. This guidance is then refined by the Deputies Committee and sent back to the CSG for refinement, or forwarded on to the NSC. Since 
9/11, the Deputies Committee has met every two weeks. Once the Deputies Committee has developed its COA, it forwards this guidance either to the NSC, chaired by the President of the USA (POTUS), or to a Principles Committee chaired by the NSA and attended by cabinet secretaries, the Director of the NCTC and the Director of the CIA. Since 9/11, this final-tier CT meeting has occurred on average every 4-6 weeks.

\section{CENTCOM/JSOC (US Central Command / Joint Special Operations Command)}

Authorisation for target selection and the use of lethal force or capture on suspected terrorist targets in the Middle Eastern region of the world falls under the authority of the CENTCOM commander, provided the region in question is a 'designated war zone'. If the area of conflict is regarded as a war zone, then authorisation for targeting, killing or capturing ends at the level of the CENTCOM commander and does not require authorisation from the NSC and POTUS. Iraq in 2003 was declared a war zone, thereby capping all decisions for conducting military (versus diplomatic) operations at the level of the CENTCOM commander. If the area of conflict is not regarded as a war zone, then the CENTCOM commander must seek authorisation and guidance from POTUS. Given that there will be issues of encroachment into state sovereignty, the greatest traditional point of friction in the NSC has often been between the DOD and DOS. Joint Special Operations Command (JSOC) assets are assigned under the authority of the CENTCOM commander, and their employment follows the same authorisation protocols.

\section{Guantanamo (GTMO)}

The Guantanamo Bay detention camp is a US military prison located within the Guantanamo Naval Base in Guantanamo Bay, Cuba. The camp was established in 2002 as part of the Bush administration's efforts in the 'war on terror'. Despite President Obama's original statement to close down the detention facility in 2009, the detention facility remains open at the time of writing (2020), though several of its sub-camps, such as Camp X-Ray, have been shut down. The total number of detainees incarcerated at Guantanamo was 780, around 500 of whom were released under President Bush's administration. Detainee numbers at the start of Obama presidency were 242, of whom 197 were transferred, repatriated or resettled under the Obama Presidency. Around 40 detainees were still held in Guantanamo in 2020. 


\section{LEGISLATION}

\section{USA Patriot Act}

The USA Patriot Act was signed into law by President George W. Bush on 25 October 2001. The Act is comprised of ten titles, each outlining ten key components of the new US counter-terrorism strategy and institutional adaptations in response to the September 11th attacks. These titles include:

- Title I: Enhancing domestic security against terrorism.

- Title II: Surveillance procedures.

- Title III: Anti-money laundering to prevent terrorism.

- Title IV: Border security.

- Title V: Removing obstacles to investigate terrorism.

- Title VI: Victims and families of terrorism.

- Title VII: Increased sharing for critical infrastructure protection.

- Title IX: Improved intelligence.

- Title X: Miscellaneous.

One of the more controversial parts of the Act was Section 215 (Access to records and other items under the Foreign Intelligence Surveillance Act). This section modified existing Foreign Intelligence Surveillance Act (FISA) legislation to allow the FBI to apply for an order to produce materials that assist in an investigation, undertaken to protect against international terrorism.

\section{Foreign Intelligence Surveillance Act (FISA)}

The FISA of 1978 was introduced on the recommendations of the Church Committee in 1978, as one of the fallouts from the Watergate scandal. The Committee was designed to investigate the conduct and possible abuses of information gathering conducted by the CIA, FBI and NSA. The FISA legislation also ushered in the Foreign Intelligence Surveillance Court (FISC, also referred to as the FISA Court). Immediately after the attacks on 9/11, Congress amended the original 1978 FISA statute in order to improve the overall connectivity and efficiency of the nation's intelligence-gathering apparatus. Beginning in 2006, the US government began using these FISA amendments under Section 215 to compel commercial telephone and cellular phone providers to hand over large amounts of metadata of their customers' phone activity. The 2013 leak by Edward Snowden about this metadata-gathering programme raised considerable controversy about the limits of government bulk surveillance of US citizens, with no specific person or specific cause for search being present. Defenders of the programme argued that the benefits of 
recognising and pre-empting future terrorist threats outweighed the perceived privacy invasions of citizens; and furthermore, that the gathering of metadata did not technically violate Fourth Amendment rights against illegal search and seizure (Pfeffer, 2015).

\section{USA Freedom Act}

In an attempt to maintain effective information-gathering capabilities while not encroaching on the privacy rights of US citizens, Congress adopted the USA Freedom Act in 2015. As Glenn Gerstell, General Counsel of the NSA puts it:

The FBI (on behalf of NSA) can apply to the FISA Court for specific authority to inquire about a particular phone number or other identifying element, but only if based on a 'reasonable, articulable suspicion' that it is associated with international terrorism ... under no circumstances does NSA get access to the content of any calls under this arrangement. (Gerstell, 2016)

Accordingly, the USA Freedom Act aims at maintaining effective information-gathering by the US intelligence community while upholding certain protections for phone companies and their customers.

\section{Authorisation for Use of Military Force against Terrorists (AUMF) and Presidential Policy Guidance (PPG) 2013}

The legal justification for US counter-terrorism efforts in recognised 'areas of active hostilities' finds its grounding in the 2001 AUMF. The 2001 AUMF grants to the President of the United States (POTUS) the legal authority to use all necessary and appropriate force against those who they determine to have 'planned, authorised, committed, or aided' the terrorist attacks on 11 September 2001. This legal document, along with its 2002 Iraq-specific instantiation, has provided the main legal justification for continued US counter-terrorism efforts for the last two administrations.

A more updated casus belli for US counter-terrorism efforts, as well as an attempt to account for new drone technologies, has been articulated in the Obama administration's PPG of 2013, which establishes the standard operating procedures for 'when the United States takes direct action, which refers to lethal and non-lethal uses of force, including capture operations against terrorist targets outside the United States and areas of active hostilities' (Obama, 2013).

The 2013 PPG outlines certain guidelines for permissible lethal targeting. These include that the target poses 'a continuing, imminent threat to US persons, 
near certainty that the target is present, near certainty that non-combatants will not be harmed, infeasibility of capture, inability or unwillingness of the host country to effectively address the threat to US persons; and an assessment that no other reasonable alternatives exist' (Lederman, 2016).

The Trump administration has since loosened some of these constraints on lethal targeting, declaring three provinces in Yemen to be 'areas of active hostilities', ostensibly providing justification for the Special Operations raid of January 2017.

\section{Title 10 and Title 50}

Title 10 provides the legal basis for all DOD and military actions, while Title 50 provides the legal basis for all CIA and covert actions. The Obama administration and the 2013 PPG arguably attempt to rein in the use and authorisation of targeted strikes within Title 10/DOD jurisdiction, and therefore within the spirit of the broader 'just war' convention. Since its inception, the Trump administration has moved the use and authorisation of targeted strikes in the opposite direction toward Title 50/CIA authority, and therefore more into domain of covert operations (Welna, 2017). Critics have argued that as the production of drone technology becomes cheaper and more expedient, and eventually in the hands of US enemies (both state and non-state actors), an international drone regime might be necessary in order to prevent drone proliferation, much as in the case of nuclear weapons (Buchanan and Keohane, 2015). It could be argued that an established precedent of increasingly covert US drone strikes might significantly undermine the establishment of just such a convention, thereby making US citizens markedly less safe from the blow-back of drone strikes in the long run.

\section{Detainee Treatment Act 2005 and Legislation on Torture}

Following First Lieutenant Ian Fishback's letter sent to Senator John McCain in September 2005, concerning the absence of clear legal and ethical guidance for the treatment of detainees as part of the ongoing global 'war on terror', the Detainee Treatment Act was passed by Congress on 30 December 2005. The Act outlines provisions concerning treatment of persons under the custody of the DOD and at the Guantanamo Bay detention centre in Guantanamo Bay, Cuba. The specifics of the Act include the prohibition of 'cruel, inhuman, or degrading treatment or punishment', the requirement that all interrogations be performed under the guidelines stated in the US Army Field Manual for Human Intelligence Collector Operations, directing the DOD to establish Combatant Status Review Tribunals, and granting legal immunity to government and military personnel who used interrogation techniques that "were 
officially authorised and determined to be lawful at the time they were conducted'. In April 2009, then-President Obama banned the use of waterboarding as an advanced interrogation method, consistent with DOD Directive 2310 (2006) that prohibited the use of cruel, inhumane and degrading treatment of detainees.

\section{COUNTER-TERRORISM STRATEGY AND TACTICS}

\section{Broad Counter-Terrorism Strategy}

The National Strategy for Counterterrorism (NSCT) of 2018 published by the Trump administration is the most current explicit articulation to date of the United States' broad CT aims and objectives. The NSCT recognises the pre-eminent security threat to the US continues to be al-Qaeda and its affiliates and adherents, as well as ISIS. The NSCT outlines six overarching CT strategy goals:

1. Pursue terrorist threats to their source.

2. Isolate terrorists from financial, material and logistical sources of support.

3. Modernise and integrate a broader set of United States tools and authorities to counter terrorism and protect the homeland.

4. Protect United States infrastructure and enhance preparedness.

5. Counter terrorist radicalisation and recruitment.

6. Strengthen the counter-terrorism abilities of international partners.

The US NSCT then articulates how these goals are to be specifically met for key areas, including: the homeland, South Asia, the Arabian Peninsula, East Africa, Europe, Iraq, the Maghreb and Sahel, Southeast Asia, Central Asia, and the area of 'information and ideas'. The United States' ultimate strategic end goal with respect to counter-terrorism is therefore to defeat not only al-Qaeda (and ISIS) but also the conditions which gave rise to its ideology and adherents (NSCT, 2018).

\section{Domestic Counter-Terrorism Strategy}

The 2016 document 'A National Strategy to Win the War Against Islamist Terror', by Chairman Michael McCaul of the House Homeland Security Committee, further outlines the US's key domestic CT priorities. These include: (1) thwarting attacks and protecting our communities; (2) stopping recruitment and radicalisation at home; (3) keeping terrorists out of the US; and (4) winning the 'war of ideas'. 


\section{Domestic Counter-Terrorism Tactics}

These broad domestic strategic goals translate into real-world CT tactics in a variety of ways. For instance, McCaul lists several tactical prescriptions, which include: JTTFs scanning social media as part of criminal background checks; denying 'virtual safe-havens' on the internet through vigilant cyber-security efforts; tightening Transportation Security Administration (TSA) vetting procedures for private sector personnel and technologies; ensuring community preparedness to respond to 'do-it-yourself'-style terrorism at home; helping local communities to be aware of red flags; developing 'off-ramps' for radicalisation; allocating significant spending for counter-terrorism counter-messaging narratives at home; enhancing screening of visitors, immigrants and refugees; and preventing prisons from becoming breeding grounds for terrorism.

In addition to these prescriptions, the NCTC's use of the TIDE database to generate terror watch lists and 'no-fly' lists functions as yet another tool in the overall set of US counter-terrorism tactics. The FBI's recent increase in the use of undercover and online sting operations (those involving the use of agents and informants to pose as jihadists, bomb-makers, weapons dealers or online 'friends') has also shown itself to be an effective tactic in thwarting potential terrorist recruitment, coordination and radicalisation efforts (Lichtblau, 2016).

\section{Foreign Counter-Terrorism Strategy}

The US CT community (and DOD more broadly) employs the diplomacy, information, military, economic (DIME) conceptual framework and the corresponding institutional agencies (State Department, NSA/CIA, Department of Defense and Treasury Department) to fight the 'war on terror'. The focus of this DIME strategy is to leverage these various powers of the state primarily to mitigate or eliminate the conditions that often give rise to terrorist threats. In this sense, the 2006 National Security Strategy (NSS) was chiefly a de-radicalisation strategy achieved mainly by way of robust troop presence on the ground, the securing of positional and infrastructural assets, the detention of adversaries, and the propping-up of new regional leadership and institutions. The 2015 NSS counter-terrorism strategy, however, diverges sharply from the 2006 NSS in several respects.

Contrary to the 2006 NSS, the 2015 NSS can be described as more of a decapitation strategy, achieved primarily through the use of targeted strikes on key leadership. The key theory driving this strategic initiative is the general notion that key leadership removal will serve the greatest positive yield in disrupting or collapsing terrorist networks. This strategic posture, however, is not without its critics, some of whom argue that such a decapitation strategy might 
fundamentally be a short-term tactical win, but ultimately a long-term strategic loss. ${ }^{1}$ More specifically, the argument against such a decapitation strategy is that the act of killing key leadership results in the mid- and long-term downstream effect of turning such local leaders into martyrs, as well as providing new substantive content for terrorist groups to utilise in future recruitment and radicalisation efforts. Despite such criticism, US counter-terrorism efforts have still relied heavily on this strategy, garnering several noteworthy strikes on high-value targets. These have included drone strikes, such as the one which killed Awlaki in Yemen in 2011; and the surgical use of special operations units for 'kill or capture' missions, such as the raid against Osama Bin Laden in his Abbotabad compound in Pakistan in 2011. This major shift in counter-terrorism strategy has coincided with a significant drawdown of US boots on the ground in both Iraq and Afghanistan, a hand-off of power to local authorities in these regions, and significantly less instances of detention. This shift to a more decapitation-oriented strategy has garnered serious criticism from both within the military and outside it.

\section{Foreign Counter-Terrorism Tactics}

Given this strategic framework, US CT tactics vary significantly according to each of the four main DIME elements. On the diplomatic front, the US State Department has taken such counter-terrorism measures as officially designating Foreign Terrorist Organizations (FTOs), as well as officially designating FTO affiliates (such as ISIS affiliates in Libya, Saudi Arabia and Yemen). The US State Department has also made great efforts to prevent foreign terrorist fighters (FTFs) from travelling to and from conflict areas such as Iraq and Syria.

In the military domain, since the official troop withdrawal from Iraq in 2011, the US has shifted its military tactical posture primarily to one of targeted drone strikes and special operations raids. For instance, under the Obama administration, a total of 563 targeted drone strikes were conducted. That being said, the US military footprint in Afghanistan still presently stands at around 14000 troops, acting mainly in an 'advise and assist' capacity alongside Afghan troops. US Army CENTCOM reports around 60000 to 70000 troops deployed to the overall Middle East area of operations (Ayesh, 2020).

On the economic front, the US Department of Treasury has also led strong efforts in the 'war on terror' by tracking the sources of suspected terrorist financing. Immediately after $9 / 11$, the US Department of Treasury initiated the Terrorist Finance Tracking Program (TFTP) to identify, track and pursue terrorists and their financial networks. Specifically, the Treasury Department has issued subpoenas to the Society for Worldwide Interbank Financial Telecommunication (SWIFT), a multinational company based in Belgium 
that handles a global financial transaction network used by banks all over the world, requesting information about suspected terrorists believed to be using the SWIFT network. Under the terms of the subpoenas, the US government was only permitted to review information as "part of specific terrorism investigations' (Sahadi, 2013). Based on information gathered, the US government is able to conduct targeted searches against the limited subset of records provided by SWIFT in order to trace financial transactions related to suspected terrorist activity.

\section{CONCLUSION}

This chapter has reviewed some of the major elements of the US counter-terrorism landscape. Specifically, it has investigated some of the major historical and geopolitical stage-setting conditions of the last half-century with respect to global terrorism. It has also looked at the US terrorism threat picture since 9/11, detailing features of al-Qaeda and ISIS. It has likewise looked at the major foreign and domestic institutional architectures within the US CT space, as well as the key CT legislation, both domestic and international. Finally, it has examined some of the major strategic and tactical means and methods currently being applied to CT operations. As the counter-terrorism threat picture continues to shift and evolve as we move further into the $21 \mathrm{st}$ century, we can anticipate similar shifting and adaptation within these CT institutions and agencies.

\section{NOTE}

1. See Johnston's (2012) paper for a thorough coverage of critics of decapitation.

\section{REFERENCES}

Ayesh, Rashaan (2020), Where US Troops and Military Assets are Deployed in the Middle East, accessed 15 April 2020 at https://www.axios.com/where-us-troops -deployed-middle-east-5e96fdb2-c7ba-4f26-90b4-7bf452f83847.html.

Brooks, R. (2015), US Counterterrorism Strategy is the Definition of Insanity, accessed 15 April 2020 at http://foreignpolicy.com/2015/06/24/u-s-counterterrorism-strategy -is-the-definition-ofinsanity/.

Buchanan, Allen and Robert O. Keohane (2015), Toward a Drone Accountability Regime, accessed 15 April 2020 at https://www.cambridge.org/core/journals/ethicsand-international-affairs/article/toward-a-drone-accountability-regime/81BCAB304 843656FC28810A29ACB4886.

Byman, Daniel L. (2015), Comparing Al Qaeda and ISIS: Different Goals, Different Targets, accessed 25 June 2020 at https://www.brookings.edu/testimonies/comparing -al-qaeda-and-isis-different-goals-different-targets/. 
Clapper, J. (2016), Worldwide Threat Assessment of the US Intelligence Community, Statement for the Record, Senate Armed Services Committee, 9 February 2016, pp. 4-6 (Terrorism Section), accessed 15 April 2020 at http://www.armed-services .senate.gov/imo/media/doc/Clapper_02-09-16.pdf.

Cole, D. (2016), The Drone Presidency, New York Review of Books, accessed 15 April 2020 at https://www.nybooks.com/articles/2016/08/18/the-drone-presidency/.

Department of Homeland Security (DHS) (2020), About DHS, accessed 25 June 2020 at https://www.dhs.gov/topic/ntas.

Gerstell, G.S. (2016) New National Security Tool Activated at Challenging Time, Lawfare website, accessed 18 January 2021 at https://www.lawfareblog.com/new -national-security-tool-activated-challenging-time.

Jenkins, B.M., A. Liepman and H.H. Willis (2014), Identifying Enemies Among Us: Evolving Terrorist Threats and the Continuing Challenges of Domestic Intelligence Collection and Information Sharing, RAND Corporation, pp. 8-16, accessed 15 April 2020 at https://www.rand.org/pubs/conf proceedings/CF317.html.

Johnston, P.B. (2012), Does Decapitation Work? Assessing the Effectiveness of Leadership Targeting in Counterinsurgency Campaigns, International Security, 36(4), 47-79. doi: 10.1162/ISEC_a_00076.

Jones, Seth (2014), A Persistent Threat: The Evolution of al Qa'ida and Other Salafi Jihadists, RAND Corporation, pp. ix-xii, 9-12, and 25-62, accessed 15 April 2020 at http://www.rand.org/content/dam/rand/pubs/research_reports/RR600/RR637/ RAND_RR637. pdf.

Lederman, Marty (2016), The Presidential Policy Guidance for Targeting and Capturing Outside Afghanistan, Iraq, and Syria, accessed 15 April 2020 at https://www .justsecurity.org/32298/presidential-policy-guidance-targetingcapture-afghanistaniraq-syria/.

Lichtblau, E. (2016), FBI Steps Up Use of Strings in ISIS Case, New York Times, accessed 15 April 2020 at https://www.nytimes.com/2016/06/08/us/fbi-isis-terrorism -stings.html? $\mathrm{r}=0$.

NSA (2020), NSA: Mission and Values, NSA Official Website, accessed 18 January 2021 at https://www.nsa.gov/about/mission-values/.

NSCT (2018), US National Strategy on Counter Terrorism, accessed 15 April 2020 at https://www.whitehouse.gov/wp-content/uploads/2018/10/NSCT.pdf.

Obama, Barack. President (2013), accessed 15 April 2020 at https://www.aclu.org/ sites/default/files/field_document/presidential_policy_guidance.pdf.

Pfeffer, Anshel (2015), Edward Snowden, Defender of Democracy or Accessory to Autocracy?, Haaretz, accessed 15 April 2020 at https://www.haaretz.com/.premium -snowden-defender-of-democracy-or-accessory-to-autocracy-1.5371842.

Ridge, T. (2002), Department of Homeland Security - About, accessed 15 April 2020 at https://www.dhs.gov/about-dhs.

Sahadi, J. (2013), What the NSA Costs Taxpayers, accessed 15 April 2020 at https:// money.cnn.com/2013/06/07/news/economy/nsa-surveillance-cost/.

Schmitt, E., H. Cooper and J.E. Barnes (2019), Trump's Syria Withdrawal Complicates Plans for al-Baghdadi Raid, accessed 15 April 2020 at https://www.nytimes.com/ 2019/10/27/us/politics/baghdadi-isis-leader-trump.html.

Sharp, J. (2016), How the Obama Administration's Drone Program Normalized Targeted Killing, accessed 15 April 2020 at https://www.pri.org/stories/2016-11-30/ how-obama-administrations-drone-program-normalized-targeted-killing.

US Senate (2018) Open Hearing: Nomination of Gina Haspel to be the Director of the Central Intelligence Agency (Senate Hearing 115-302), Washington, DC: US 
Government Publishing Office, accessed 3 July 2019 at https:/www.congress.gov/ 115/chrg/CHRG-115shrg30119/CHRG-115shrg30119.htm.

Welna, David (2017), Trump Restores CIA Power to Launch Drone Strikes, accessed 15 April 2020 at https://www.npr.org/2017/03/14/520162910/trump-restores-cia -power-to-launch-drone-strikes. 